\title{
PERAN MASJID DALAM DAKWAH MENURUT PANDANGAN MOHAMMAD NATSIR
}

\author{
P-ISSN: 2085-4536 | E-ISSN: 2721-7183 \\ Link: https://jurnal-stidnatsir.ac.id/index.php/binaummat/article/view/50 \\ DOI : https://doi.org/10.38214/jurnalbinaummatstidnatsir.v2i02.50
}

Dikirim: 25-03-2019

Direview: 05-04-2019

Diterbitkan: 17-04-2019

\author{
ASWAN HAIDI \\ aswan@stidnatsir.ac.id \\ STID Mohammad Natsir - Indonesia
}

\begin{abstract}
ABSTRAK
Tujuan Penelitian: Untuk mengungkap peran masjid dalam dakwah menurut pandangan Mohammad Natsir. Metode Penelitian: Kualitatif. Hasil Penelitian: Menurut Mohammad Natsir, peranan masjid dalam dakwah ada empat hal. Pertama, masjid sebagai tempat ibadah. Namun Pak Natsir membuat garis yang sangat jelas, bahwa maksud fungsi masjid sebagai tempat ibadah mencakup ibadah konvensional; seperti shalat dan lain sebagainya, juga ibadah ghairu mahdhah yang meliputi semua aktifitas manusia terhadap sesama dan alam di sekitarnya. Dengan kata lain, ibadah yang mencakup hablum minallah wa hablum minannas. Kedua, masjid sebagai tempat Pendidikan dan Pembinaan. Pak Natsir memberikan penerangan kepada masyarakat, sudah saatnya untuk memulai usaha baru, yaitu membina masyarakat melalui masjid; sebagai usaha memfungsikan masjid dengan selayaknya. Ketiga, masjid sebagai tempat membangun karakter. Pak Natsir memberikan jawabannya sendiri: "Masjid dapat berperanan membangun, dan memang tugasnya membangun manusia. Yaitu membangun kepribadian manusia untuk membangun. Membangun pribadi manusia merupakan unsur terpenting dalam tiap kegiatan pembangunan. Keempta, masjid sebagai Benteng Pertahanan Umat Islam. Keberadaan masjid sangat diharapkan dapat memberikan "tameng yang kuat" kepada para jamaah sehingga dapat membedakan mana yang hak dan mana yang bathil. Ini adalah bekal mental dan pikiran. Secara bersamaan juga harus menjadi tumpuan jamaah dalam mengasah kemampuan fisiknya guna menghadapi pihak lawan jika dimungkinkan
\end{abstract}

Kata Kunci: Peran masjid, dakwah, Mohammad Natsir 


\section{PENDAHULUAN}

Sejarah telah menunjukkan, bahwa masjid sejak zaman Rasulullah $\varepsilon$ telah menjadi markas kegiatan kaum Muslimin. Akan tetapi ia tidak sematamata digunakan untuk kegiatan ritual saja, namun mencakup seluruh kegiatan masyarakat secara konfrehensif. Ini terbukti dengan perannya yang tidak kecil dalam pembangunan peradaban Islam. Dalam The Cultural Atlas of Islam, Ismail Faruqi mengatakan artefak peradaban Islam masa lalu tidak dapat dipisahkan dari pembangunan masjid. ${ }^{1}$

Keberadaan masjid merupakan simbol eksistensi masyarakat Muslim. Ia juga cermin persatuan dan kesatuan dalam ikatan etika persaudaraan Islami. Di masjidlah umat Islam melaksanakan ibadah ritual sebagai kewajiban sebagai hamba Allah I. Di tempat yang sama pula umat Islam melaksanakan ibadah sosial lainnya yang lebih berdimensi kemanusiaan. ${ }^{2}$ Maka wajar ketika Rasulullah $\varepsilon$ membangun masyarakat Muslim Madinah, yang pertama kali dibangun adalah masjid sebagai wahana pembina mental kaum Muslimin, tempat musyawarah, tempat pendidikan, bahkan latihan militer sekaligus. ${ }^{3}$ Dengan demikian, sangat tepat sekali apa yang dinyatakan oleh Muhammad Said Ramadhan Al-Buthy bahwa masjid adalah asas utama yang terpenting bagi pembentukan masyarakat islami. Masyarakat tidak akan terbentuk secara kokoh dan rapi kecuali adanya komitmen terhadap sistem aqidah dan tatanan kehidupan yang islami. Hal ini hanya dapat tumbuh dan terwujud dengan semangat masjid. ${ }^{4}$

Pak Natsir dalam menjalankan Da'wah demi tercapainya masyarakat yang beriman dan bertaqwa kepada Allah Ta'ala, tidak terlepas Tiga Pilar Umat Islam, yaitu Masjid, Kampus dan Pesantren. ${ }^{5}$ Dalam pandangan beliau, Masjid adalah tempat pembinaan pribadi dan jiwa seluruh lapisan masyarakat tanpa terkecuali, baik yang kaya, miskin, para intellektual, anak-

\footnotetext{
${ }^{1}$ Herman K. Dipojono, Masjid sebagai Pusat Informasi untuk Membentuk Komunitas Belajar Berbasis Masjid, Makalah, e-mail: dipojono@tf.itb.ac.id, hal. 1.

${ }^{2}$ Nana Rukmana, Masjid dan Da'wah; Merencanakan, Membangun dan Mengelola Masjid, Jakarta: Al-Mawardi Prima, Juli 2002, cet. 1, hal. XIII.

${ }^{3}$ Ibid, hal. XIV.

${ }^{4}$ Muhammad Said Ramadhan Al-Buthy, Sirah Nabawiyyah, Jakarta: Rabbani Press, 1999, hal. 171

${ }^{5}$ M. Natsir, Pendidikan, Pengorbanan, Kepemimpinan Primordialisme dan Nostalgia, Jakarta: Media Da'wah, 1987, cet. I, hal. 9.
} 
anak jalanan, orang tua, pemuda dan anak-anak. Sementara Kampus atau Universitas dapat membentuk dan menghasilkan para cendikiawan yang ahli dalam bidang ilmu pengetahuan umum dan teknelogi yang bisa memenuhi kebutuhan masyarakat di era globalisasi ini. Adapun Pesantren dapat menciptakan para ulama, para ustadz yang ahli dalam ilmu pengetahuan agama. ${ }^{6}$

Dalam realitanya, Pak Natsir termasuk konsisten dalam berjuang melalui tiga pilar itu. Apabila tiga komponen yang menjadikan basis pergerakan da'wah itu dipertemukan maka akan menjadi "mesin besar" yang memproduksi manusia unggul yang beriman, bertaqwa, berilmu dan beramal untuk kemaslahatan baik individu atau kelompok di segala bidang, dari tingkat RT sampai tingkat negara, nasional maupun internasional, dunia maupun akhirat. Sebaliknya amat sangat berbahaya jika terjadi dikotomi antara ke-tiga pilar itu, sehingga manusia hanya cendrung pada spesialisasi tertentu dan menafikan bidang lain. Hal ini akan menyebabkan sikap apatis terhadap bidang diluar keahliannya. Dampak dari dikotomi itu misalnya, seorang insinyur bangunan atau dokter dan lainnya tidak memberikan perhatian kepada agama. Ketika berkiprah di masyarakat tidak memecahkan masalah, tapi sebaliknya akan membuat masalah baru. ${ }^{7}$ Untuk mewujudkan semua itu, Pak Natsir dengan Dewan Da'wah Islamiyah Indonesia yang didirikannya terus membangun masjid, kampus dan pesantren di berbagai daerah di Nusantara.

\section{Deskripsi Buku "KH. Hasan Basri 70 Tahun; Fungsi Ulama Dan Peranan Masjid"}

Buku "KH. Hasan Basri 70 Tahun; Fungsi Ulama dan Peranan Masjid" ditulis oleh Ramlan Mardjoned, diterbitkan oleh Media Da'wah

\footnotetext{
${ }^{6}$ Misbach Malim, Dinamika Da'wah; Dalam Perspektif Al-Qur'an dan As-Sunnah, Jakarta: Media Da'wah, 2005, cet. I, hal. 43. Pada saat sekarang ini sudah banyak lembaga baik agama, sosial maupun pendidikan yang menyatukan tiga komponen itu, dimana ada masjid, disitu ada lembaga pendidikan. Dimana ada Kampus maka disitu ada pula masjid. Dan tidak sedikit kampus atau masjid kampus yang dikelola dengan pola pembinaan yang ada di pesantrenpesantren.

${ }^{7}$ M. Natsir, Pendidikan, Pengorbanan, Kepemimpinan Primordialisme dan Nostalgia, Ibid. hal. 9.
} 
yang beralamat Jl. Kramat Raya 45 Jakarta Pusat. ${ }^{8}$ Buku ini dicetak pertama pada tahun 1411/1990. Buku setebal 386 halaman ini menggambarkan apa dan siapa KH. Hasan Basri.' Sementara H.S. Prodjokusumo, Sekretaris Umum Dewan Pimpinan MUI mengatakan bahwa tujuan penulisan buku ini adalah untuk mengungkapkan perjalanan $\mathrm{KH}$. Hasan Basri selama tiga perempat bagian dari usianya sebagai pemimpin Ulama. ${ }^{10}$

Buku ini terdiri dari tiga bagian; Bagian Pertama menceritakan tentang lingkungan keluarga KH. Hasan Basri. Bagian Kedua tentang Perjuangan Gerilya dan Politiknya dan Bagian Ketiga berisi Da'wah Bil hal, dilengkapi dengan tulisan-tulisan KH. Hasan Basri sebanyak 14 judul. ${ }^{11}$

Penulis sadar, bahwa jika diurut dari awal, maka peranan masjid itu sangatlah banyak. Dalam tulisan ini, Penulis hanya menguraikan ungkapanungkapan Pak Natsir yang berkaitan dengan Peranan Masjid dan Strategi Pembangunan Masjid dalam Buku "KH. Hasan Basri 70 Tahun; Fungsi Ulama dan Peranan Masjid" Bagian Ketiga; Da'wah Bil-Hal dengan Sub Judul "Peranan Masjid" halaman 183-196 saja.

Oleh karena itu, penulis akan merealisasikannya dalam penelitian yang cukup mendalam dan mewujudkannya dalam sebuah karangan Ilmiyah dengan judul: MOHAMMAD NATSIR DAN MASJID. (Studi Analisis

\footnotetext{
${ }^{8}$ Panitia Buku Peringatan 70 Tahun KH. Basri adalah: Penasehat: KH. Abdullah Salim. Ketua: H.S. Prodjo Kusumo. Wakil Ketua I: Dr. H. Anwar Harjono, SH. Wakil Ketua II: H. Fahmi Idris. Sekretaris: Ramlan Mardjoned, Wakil Sekretaris I: H.M.I. Anshary, Wakil Sekretaris II: Johar Arifin. Bendahara: Ny. Zen Hasbullah, Wakil Bendahara: Muttahid Ajwar. Anggota: H.M. Yunan Nasution, Dr. Hariri Hadi, Bukhari Tamam, Rusydi Hamka, Abdul Wahid Zaini, Natsir Zubaidi dan Badruzzaman Busyairi.

${ }^{9}$ Anwar Haryono, Pengantar KH. Hasan Basri 70 Tahun; Fungsi Ulama dan Peranan Masjid. Media Da'wah: Jakarta, cet. 1, 1411/1990, hal. VI.

${ }^{10}$ H.S. Prodjokusumo, Sekretaris Umum Dewan Pimpinan MUI, Sambutan MUI, dalam KH. Hasan Basri 70 Tahun; Fungsi Ulama dan Peranan Masjid, Ibid, hal. XI. Pada saat sambutan buku ini ditulis, Majelis Ulama Indonesia sedang besiap-siap untuk mengadakan MUNAS IV MUI pada tangga 20-25 Agustus 1990 untuk menetapkan pengurus MUI periode 1990-1995.

11 Tulisan KH. Hasan Basri yang dimaksud adalah: Kepemimpian Majelis Ulama, Bersyukur dan Tafakkur, Badan Musyawarah Antar Ummat Beragama, Kerukunan Ummat Beragama di Indonesia, Islam Melarang Nikah Antar Agama, Sekitar Peningkatan Perjalanan Haji, Keputusan dan Saran-sran dari Majma' Buhuts Al-Islamyah, Catatan Ringkas dalam Loka Karya Muballigh, Catatan Kenangan Untuk Buya Hamka, Muhammad Natsir Khadimul Ummah, Menyabut Tahun Baru Apa yang Perlu kita Persiapkan? Membina Taqwa dan Disiplin Diri Lima Sifat Pemimpin dan Mantapkan Iman di Tengah Pergolakan Dunia.
} 
Ungkapan Mohammad Natsir dalam Buku "KH. Hasan Basri 70 Tahun; Fungsi Ulama dan Peranan Masjid").

\section{HASIL DAN DISKUSI}

\section{Peranan Masjid Menurut Pak Natsir}

\section{Tempat Beribadah}

Dalam buku "KH. Hasan Basri 70 Tahun; Fungsi Ulama dan Peranan Masjid", Pak Natsir menyatakan: Kiranya sudah dipahami, fungsi masjid adalah pembangunan ummat dalam arti yang luas dari tempat beribadah dalam arti yang konvensional, yaitu tempat shalat. Dengan lain perkataan, semua kegiatan seorang hamba Allah I, baik berupa ibadah shalat, zakat, shaum dan haji, ataupun muamalah (pengembangan kemasyarakatan) antara sesama manusia dengan meningkatkan kesejahteraan, dilakukan dalam rangka persembahan kepada Allah I dengan motif (niat) hendak mencapai Ridha Allah I semata-mata. Menyembah Allah I bukan berarti meninggalkan hidup duniawi. Bahkan fungsi manusia di dunia ini adalah khalifatun fil ardhi (wakil Allah di atas bumi). ${ }^{12}$

Fungsi pertama masjid yang diungkap dalam buku "KH. Hasan Basri 70 Tahun; Fungsi Ulama dan Peranan Masjid" adalah tempat ibadah kepada Allah Ta'ala semata dengan tidak meninggalkan urusan dunia. Karena tidak bisa dipungkiri bahwa fungsi manusia di dunia ini adalah khalifatun fil ardhi (wakil Allah I di atas bumi), yang memakmurkan bumi dengan segala isinya.

Namun Pak Natsir membuat garis yang sangat jelas, bahwa maksud fungsi masjid sebagai tempat ibadah mencakup ibadah konvensional; seperti shalat dan lain sebagainya, juga ibadah ghairu mahdhah yang meliputi semua aktifitas manusia terhadap sesama dan alam di sekitarnya. Dengan kata lain, ibadah yang mencakup hablum minallah wa hablum minannas. Di masjidlah terbentuk perpaduan antara kedua bidang kehidupan itu. Beliau pernah memberikan taushiyah kepada Jamaah bahwa: "Supaya kedua-duanja seimbang. Islam tidak menjuruh kita terus menerus dari pagi sampai sore, sampai malam, tetap terus-menerus dalam masdjid

${ }^{12}$ Ramlan Mardjoned, KH. Hasan Basri 70 Tahun; Fungsi Ulama dan Peranan Masjid, Ibid, hal. 195. 
untuk bershalat, untuk berdo'a, akan tetapi Islam menjuruh kita pergi ke masdjid untuk menghubungkan diri kita, jiwa kita dengan Allah Swt dan kita menghubungkan "silaturrahmi" kita uchuwah kita dengan hidup sesama manusia". ${ }^{13}$

Dalam kajian sejarah, apa yang dikatakan Pak Natsir tersebut diatas sangat sesuai dengan apa yang telah dicontohkan oleh Rasulullah $\varepsilon$, para Shahabat dan generasi setelahnya. Sebagai bukti, Abdullah Ibn Mas'ud pernah mengungkapkan bahwa tiada yang ketinggalan shalat berjamaah di masjid kecuali orang munafik. ${ }^{14}$ Imam Al-Baghawi ketika menjelaskan fungsi masjid adalah: Al-Mawadhi' allati buniat lis Shalati wa dzikrillah; Tempat untuk melaksanakan ibadah shalat dan berzikir (mengingat Allah I). ${ }^{15}$ Sementara Ibnu Jauzi merujuk kepada pendapat Ibn Abbas, yang menguatkan bahwa fungsi mesjid sesungguhnya adalah untuk melaksanakan Ibadah shalat. ${ }^{16}$

Di baris terakhir, Pak Natsir mengatakan: "...dilakukan dalam rangka persembahan kepada Allah I dengan motif (niat) hendak mencapai Ridha Allah I semata-mata, menunjukkan bahwa motif dari ibadah itu semua adalah semata-mata untuk mencari keridhaan Allah I saja dan tidak ada niat lain. Ungkapan itu tidak menyelisihi para ulama' shalafusshaleh. ${ }^{17}$

\footnotetext{
${ }^{13}$ Muhammad Natsir, Kearah Pembinaan dan Pembelaan Ummat; Innama Tunsharuna bi Dhu'afa', Djakarta: Jajasan Masdjid Al-Munawwarah, hal. 17.

${ }^{14}$ Abdullah Ibn Mas'ud t berkata: "Saya melihat semua kami (para Shahabat) menghadiri jama'ah. Tiada yang ketinggalan menghadiri jama'ah, selain dari orang-orang munafiq yang telah nyata kemunafiqannya, dan sungguhlah sekarang dibawa ke Masjid dipegang lengannya oleh dua orang, seorang sebelah kanan, seorang sebelah kiri, sehingga didirikannya ke dalam shaff." (HR. Al-Jamaah selain Al-Bukhari dan Turmudzy).

${ }^{15}$ Al-Baghawi, Tafsir Al-Baghawi, hal. 573.

${ }^{16}$ Ibn Jauzi mengatakan ketika disebut Masjid Allah, maka akan mengandung 4 pendapat (makna): (1). Masjid adalah rumah untuk melaksanakan shalat, ini adalah pendapat Ibn Abbas

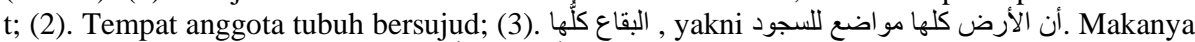

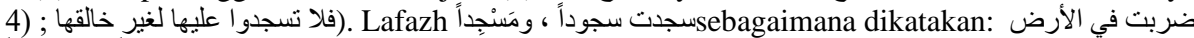

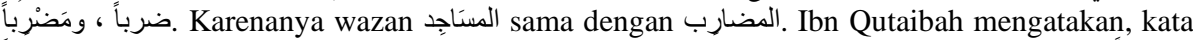

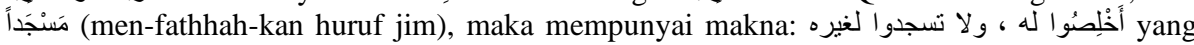
berarti: Ikhlash dan tidak melakukan sujud kepada selain Allah. (Lih. Al-Imam Abi al-Faraj 'Abdur Rahman Ibn Al-Jauzi Al-Quraisyi Al-Baghdadi, Zadul Masir fi 'Ilmi At-Tafsir, Beirut: Al-maktabu AL-Islamy Li Thaba'ati wa An-Nasyri, 1968, cet. 8, hal. 382).

${ }^{17}$ Al-Imam Abi al-Faraj 'Abdur Rahman Ibn Al-Jauzi Al-Quraisyi Al-Baghdadi, Zadul Masir fi 'Ilmi At-Tafsir, Ibid.
} 


\section{Tempat Pendidikan dan Pembinaan}

Dalam ceramah yang diucapkan pada upacara Pembukaan Madrasah Tarbijah Mu'allimin, Masjid Baitul Ma'mur Pasar Kodja-Tanjung Periuk, Pak Natsir mengatakan: ...Kita berada di masdjid jang sedang di bangun. Dan pada hari ini, kita hendak memulai satu usaha baru, sebagai kelandjutan pembinaan masdjid ini, jaitu meningkatkan kepada pendidikan. Sebenarnja, tidak biasa orang mendidirkan satu sekolah di dalam masdjid bersama-sama. Oleh karena orang menganggap, masdjid adalah masdjid, sekolah adalah sekolah. Oleh karena orang menganggap bahwa madjid adalah tempat beribadah, dan sekolah tempat beladjar.... ${ }^{18}$

Pak Natsir sudah membaca paradigma yang berkembang di masyarakat bahwa masjid hanyalah untuk shalat saja, bukan untuk kegiatan lain.

“... Oleh karena orang menganggap, masdjid adalah masdjid, sekolah adalah sekolah. Oleh karena orang menganggap bahwa madjid adalah tempat beribadah, dan sekolah tempat beladjar. Makanya Pak Natsir memberikan penerangan kepada masyarakat, sudah saatnya untuk memulai usaha baru, yaitu membina masyarakat melalui masjid; sebagai usaha memfungsikan masjid dengan selayaknya". ${ }^{19}$

AM. Saefuddin menambahkan, semenjak awal kebangkitan Islam, masjid merupakan taman pendidikan. ${ }^{20}$ Rasulullah $\varepsilon$ sendiri memberikan teladan dalam membina dan mendidik para Shahabat di dalam masjid. Tradisi ini dilanjutkan oleh para Tabi'in dan Tabi'it Tabi'in. ${ }^{21}$ Maka sudah

18 Diungkapkan Pak Natsir pada Upacara Pembukaan Madrasah Tarbijah Mu'allimin, Masdjid Baitul Ma'mur, Pasar kodja Gg. V, Tandjung Priuk, pada tanggal 19 Muharram 1388/17 April 1968. lih. Muhammad Natsir, Kearah Pembinaan dan Pembelaan Ummat; Innama Tunsharuna bi Dhu'afa', Djakarta: Jajasan Masdjid Al-Munawwarah, hal. 15.

${ }^{19}$ Buraidah t berkata, bahwa Rasulullah $\varepsilon$ bersabda: Masjid itu dibangun hanyalah untuk kepentingan yang sesuai dengan fungsinya." (Muslim, 569, Lih. Syaikh Salim Al-Hilali, Shahih Kitab Al-Adzkar wa Dha'ifuhu, no. 72.

20 AM. Saefuddin, Fungsi Masjid sebagai Fakultas Dzikir dan Amal. Lih. Kumpuan Buletin Dakwah, No. 1 s/d 52 thn. 1987. Bunga Rampai Ajaran Islam 14, Jakarta: Dewan Da'wah Islamiyah Indonesia, 1993, hal. 242.

${ }^{21}$ Mohammad Syadid mengatakan: ... Keberhasilan Beliau $\varepsilon$ dalam bidang pendidikan tidak tertandingi sepanjang perjalanan sejarah kemanusiaan. Keberhasilan Beliau $\varepsilon$ dalam mencapai tujuan yang tinggi dan luhur bersama masyarakat Madinah, tidak pernah dicapai oleh para filosof, pemikir dan para reformer pendidikan sekalipun, kecuali hanya dalam angan dan khayalan." (Mohammad Syadid, Konsep Pendidikan Dalam Al-Qur'an, Jakarta: Penebar Salam, 1442 H./2001 M., cet. 1, hal. 4-5). 
selayaknya di era modern ini, masjid juga harus mampu menjadi Pusat Ilmu dan Pusat Da'wah Islamiyah. Keberadaannya dalam rangka meningkatkan dan menumbuh-kembangkan wawasan serta pengetahuan keislaman sebagai wujud kepedulian sekaligus kewajiban menegakkan nilai-nilai keislaman di tengah-tengah masyarakat. ${ }^{22}$

\section{Tempat Membangun Karakter (Kepribadian)}

Dalam "Suara Masjid", Pak Natsir menghubungkan fungsi masjid dengan kegiatan pembangunan, seraya bertanya: "Sampai dimanakah dan dengan cara bagaimanakah masjid itu dapat berpartisipasi dalam usaha pembangunan itu?" Bukankah sudah ada lembaga-lembaga pemerintah dan swasta yang menggarap pembangunan dengan berbagai macam bentuknya, secara lansung dan lengkap dengan anggaran biayanya. Perlengkapan alat teknikya modern, ada para ahli teknotratnya dari bermacam-macam bidang keahliannya, yaitu bidang pertanian, perindustrian, perkapalan dan sebagainya. Apalagi yang diharapkan dari peranan masjid dalam soal pembangunan ini"?

Pak Natsir memberikan jawabannya sendiri: "Masjid dapat berperanan membangun, dan memang tugasnya membangun manusia. Yaitu membangun kepribadian manusia untuk membangun. Membangun pribadi manusia merupakan unsur terpenting dalam tiap kegiatan pembangunan. Hasil pembagunan itu banyak tergantung kepada sikap jiwa dan tingkah laku dari unsur manusia yang menyelenggarakan usaha pembangunan itu sendiri. Manusia itu bukan robot yang bisa diputar dengan per atau komputer. Manusia adalah mahluk berpikir, mempunyai rasa, mempunyai cita-cita, mempunyai pandangan hidup dan adat istiadat, bahkan mempunyai hawa nafsu".

Pak Natsir melanjutkan: "Manusia dengan ilmunya bisa membangun dan menciptakan. Tapi dengan hawa nafsu, ia bisa sesudah itu atau berbarengan dapat pula merusak dan meruntuhkan apa yang dibangunnya". Dalam pandangan Pak Natsir, untuk membangun suatu negara atau bangsa dibutuhkan manusia yang memiliki sifat dan karakter membangun.

22 Para Ulama' berpandangan, bahwa Rasulullah $\varepsilon$ senantiasa mensejajarkan antara menuntut ilmu dan berda'wah (kewajiban berda'wah), tidak mengurangi dan tidak pula melebihkannya. (Sayyid Muhammad Nuh, Strategi Da'wah dan Pendidikan Umat, Yogyakarta: HIMAM-Prisma Media, April 2004, cet. 1, hal. 155-156). Sebab da'wah dan pendidikan adalah kebutuhan mendesak dan tidak bisa ditunda. (Lihat Sayyid Muhammad Nuh, Urgenitas Da'wah dan Pendidikan, Ibid, hal. 39-59). 
Sementara manusia itu sendiri memiliki keberagaman karakter, manusia punya akal, rasa, cita-cita, juga mempunyai pandangan hidup dan adat istiadat serta nafsu yang senantiasa cendrung kepada kejahatan. Pak Natsir menambahkan bahwa dengan sifat manusia yang beragam itu sangat tidak mungkin menjadikan manusia "langsung jadi" akan tetapi perlu proses waktu dan tahapan-tahapan. "Manusia itu bukan robot yang bisa diputar dengan per atau komputer", ungkap Pak Natsir. Oleh karena itu fungsi masjid yang dicontohkan Rasulullah $\varepsilon$ adalah merubah karakter manusia menjadi manusia berakhlaq dan bermoral. ${ }^{23}$ Inilah solusi yang diberikan Pak Natsir untuk mempersiapkan generasi yang membangun bangsa. Beliau mengatakan: "Disinilah terletak sesungguhnya bidang kegiatan masjid dan lembaga-lembaga kemasjidan, yakni dalam membangun manusia, agar bisa membangun sebenar membangun. Memberantas kecendrungan manusia untuk merusak hasil yang dituju oleh pembangunan itu". ${ }^{24}$ Apalagi jika masjid dikelola dengan cara profesional, maka akan melahirkan generasi yang 'alim (intelektual), 'abid (ahli ibadah) dan mujahid (para pejuang yang konsisten dengan nilai-nilai Islam), sehingga bangga sebagai seorang Muslim, dan mampu mengamalkan serta menda'wahkan agamanya sendiri.

\section{Masjid adalah Benteng Pertahanan Umat Islam}

Masjid adalah pangkalan umat Islam berangkat melaksanakan perjuangan. Masjid juga merupakan benteng pertahanan di waktu perang dan pusat pembangunan semasa damai. ${ }^{25}$ Jika masjid sebagai lembaga pertama dan utama tidak ikut berkembang, maka akan putuslah ikatan kesatuan sosial muslim, pecahlah keseimbangan, bahkan sirnalah pusat daya Islam untuk memimpin, menuntun dan menjawab tantangan-

23 Mohammad Syadid mengatakan: ... keberhasilan yang Rasulullah $\varepsilon$ capai ini menunjukkan betapa pendidikan yang dimulai di masjid memiliki kemampuan yang ampuh untuk merubah jiwa manusia dari karakter biadab menjadi manusia beradab, sehingga mengantarkan umat pada keluhuran kemanusiaan ke tingkat yang paling tinggi. (Mohammad Syadid, Konsep Pendidikan Dalam Al-Qur'an, ibid, hal. 4-5).

${ }^{24}$ Ramlan Mardjoned, KH. Hasan Basri 70 Tahun; Fungsi Ulama dan Peranan Masjid. Media Da'wah: Jakarta, cet. 1, 1411/1990, hal.

${ }^{25}$ Ramlan Marjonet, KH. Hasan Basri 70 Tahun, Fungsi Ulama dan Peran Masjid, Ibid, hal. 184-186. 
tantangan zaman. ${ }^{26}$ Pak Natsir saat meresmikan pemakaian Masjid AlFurqan mengatakan: "... Al-Furqan adalah satu nama Al-Qur'an, dan salah satu dari nama Surah di dalam Al-Qur'an, yaitu Surah ke-25. Al-Furqan berarti pemisah atau criterium antara haq dan bathil. Al-haq yang berwujud dalam penghambaan kepada kekuasaan dan hukum Allah semata-mata. AlBathil yang berwujud kepada bukan Allah I. Pertarungan antara haq dan bathil berlaku sepanjang masa. Tidak semata-mata berupa fisik, tetapi yang tidak kurang beratnya adalah yang disebut: pertarungan pemikiran, pertarungan antara konsep dengan konsep, ideologi dengan ideologi, yang tidak ada teduhnya". ${ }^{27}$

Keberadaan masjid sangat diharapkan dapat memberikan "tameng yang kuat" kepada para jamaah sehingga dapat membedakan mana yang hak dan mana yang bathil. Ini adalah bekal mental dan pikiran. Secara bersamaan juga harus menjadi tumpuan jamaah dalam mengasah kemampuan fisiknya guna menghadapi pihak lawan jika dimungkinkan. ${ }^{28}$

\section{Konsep Pak Natsir Dalam Membangun Masjid}

"Selama masjid berurat tunggang ke dalam masyarakat dan didukung oleh para jamaah serta ummat, walaupun badai angin topan yang datang melanda, gelombang menggulung tinggi di tengah samudra luas, masjid akan tetap berdiri tegak, sebagai lembaga hidup yang memancarkan alikhtsir-penawar hidup bagi ummat sekitarnya." 29

Dari ungkapan Pak Natsir diatas, paling tidak ada tiga hal yang menjadi catatan penting:

${ }^{26}$ Sidi Gazalba, Masjid Pusat Ibadat dan Kebudayaan Islam, Jakarta: Pustaka Antara, 1975, cet. III, hal. 134-135.

${ }^{27}$ Tulisan itu disampaikan oleh Pak Natsir ketika meresmikan pemakaian Masjid Al-Furqan yang baru dibangun (rehabilitasi) pada tanggal 21 Rabi'ul Akhir 1410 H/20 November $1988 \mathrm{M}$. Lih. Serial Khutbah Jum'at, No. 92, Th. VI Rajab 1409 H/Februari 1989 M, sebagaimana yang dikutip dalam Ramlan Mardjoned, KH. Hasan Basri 70 Tahun; Fungsi Ulama dan Peranan Masjid, Ibid, hal. 194-195.

${ }^{28}$ Rasulullah telah mengajarkan dan melatih para Shahabat berperang di masjid. (Lih. AlBukhari, Kitab Shalah, Bab: Ashhabul Harab fil Masjid, 454, Muslim, Shalatul 'Idain, Bab: ArRukhshah fil La'bi Alladzi La Ma'shiyata fih, 892).

29 Intisari ceramah Mohammad Natsir saat memberikan taushiyah di Masjid AlMunawwarah Tanah Abang-Jakarta Pusat. Lih. Ramlan Mardjoned, KH. Hasan Basri 70 Tahun; Fungsi Ulama dan Peranan Masjid. Ibid, hal. 195-196. 


\section{Konsep/cara membangun masjid}

2. Tantangan dalam da'wah

\section{Konstribusi masjid}

\section{a. Konsep/Cara Membangun Masjid}

"Selama masjid berurat tunggang ke dalam masyarakat dan didukung oleh para jamaah serta ummat..." Pak Natsir dalam membangun masjid, selalu melibatkan warga masyarakat yang ada di wilayah masjid yang akan dibangun. Dengan swadaya masyarakat itu, dan dilaksanakan dengan cara gotong royong akan lebih menjadikan suasana kebersamaan dan sepenanggungan. Strategi yang digunakan Pak Natsir dalam membangun masjid tersebut sangatlah berpengaruh untuk masa yang akan datang.

1. Masyarakat benar-benar akan merasa bahwa masjid yang dibangun adalah milik warga yang harus dijaga eksistensinya;

2. Warga akan merasa bertanggungjawab atas kemakmuran dan keberlansungan kegiatan masjid;

3. Jika eksistensi masjid itu diganggu, maka tidak akan merepotkan pedirinya (Pak Natsir atau Dewan Da'wah), akan tetapi masyarakatlah yang akan membela dan menyelesaikan masalah tersebut.

Kita bisa melihat perjalan Sirah, ketika Rasulullah $\varepsilon$ membangun Masjid Quba, demikian pula masjid Nabawi. Rasulullah $\varepsilon$ bekerja secara bahu membahu bersama para Shahabat. ${ }^{30}$ Bahkan Rasulullah $\varepsilon$ ikut terlibat

\footnotetext{
${ }^{30}$ Beberapa bait syair di bawah ini adalah salah satu bukti Mu'awanah wa Al-Muasyarah fi Binai Masjid antara Rasulullah $\varepsilon$ dan Para Shahabat Muhajirin dan Anshar y. هذا الحِمَالُ لا حِمَالُ "Barang bawaan ini bukan bawaan ke negeri Khaibar, tetapi lebih baik bagi kami dan lebih suci." (Abu Muhamad Al-Husain Ibn Mas'ud Ibn Muhammad Al-Farra' AlBaghawy Asy-Syafi'i, Tafsir Al-Baghawy, 4/52. Lih. Shahih Al-Bukhari, Bab: Hijrah Nabi \&, no. 3694, 2/1421. Lihat juga Ibn Hisyam, Sirah Nabawiyah, 1/495). Rasulullah $\varepsilon$ bersabda: اللهم "Ya Allah, sesungguhnya pahala itu adalah pahala akhirat, maka limpahkanlah Rahmat-Mu pada kaum Anshar dan Muhajirin.” (Ibn Hisyam, Sirah Nabawiyah, 1/ 495). Para Shahabat y yang mendengar syair Nabi $\varepsilon$ kemudian berpantun: لئن قغنا ل "Jika kami duduk saja, sementara Nabi $\varepsilon$ bekerja keras. Sungguh yang demikian merupakan hal yang menyesatkan." Adakalanya Rasulullah $\varepsilon$ dan para Shahabat
} 
membawa batu saat membangun masjid tersebut. Pak Natsir juga dalam suatu ceramah menjelaskan hadits ini.

Ibnu Atsir, Jami' Al-Ushul min Ahadits Ar-Rasul menceritakan: Ketika seorang Shahabat melihat Rasulullah $\varepsilon$ mengangkat tanah, dan mengatakan: "Wahai Rasulullah, biarlah saya yang membawa batu itu!" Rasulullah $\varepsilon$ mengatakan: "Pergilah, ambillah batu yang lain! ....."31

\section{b. Tantangan Dalam Da'wah}

“... walaupun badai angin topan yang datang melanda, gelombang menggulung tinggi di tengah samudra luas, masjid akan tetap berdiri tegak...",

Ketika basis da'wah, yaitu masjid sudah menjalankan aktivitas da'wahnya, menyeru masyarakat kepada yang ma'ruf dan mencegah dari yang mungkar, maka tantangan dan ujian pasti akan datang melanda. Jadi Pada saat seperti itulah dibutuhkan da'wah yang penuh hikmah dan bijaksana. Jika jamaah sudah merasa memiliki masjid dan bertanggungjawab atas keberlansungan masjid, maka masjid itu akan tetap eksis dan diakui keberadaannya baik oleh masyarakat maupun oleh pihak lawan.

\section{c. Konstribusi Masjid}

“... sebagai lembaga hidup yang memancarkan al-ikhtsir-penawar hidup bagi ummat sekitarnya." Keberadaan masjid yang dibangun oleh masyarakat harus menjadi "Mensin Penyelesaian" masalah yang terjadi di masyarakat dalam segala bidang, baik pribadi, keluarga, masyarakat luas maupun problematika yang dihadapi bangsa dan negara. Makanya, masjid harus menebarkan kesejukan, kedamaian, keramahan budi, kemuliaan

y, serentak mengatakan: 'اللهم لاعيش الا عيش الآخرة ، فاغفر للانصار والمهاجرة" Aa Allah, tiada kehidupan kecuali kehidupan di akhirat, maka ampunkanlah dosa kaum Anshar dan Muhajirin. (HR. Al-Bukhari dari Ahmad Ibn Al-Muqaddam. Lih. Mu'jam Al-Kabir, 5959, 2/187. Sunan Kubra Al-Baihaqy, 7/48. Lihat juga Ibn Hisyam, Sirah Nabawiyah, 1/495). Itulah suasana yang penuh kasih sayang membuat pekerjaan menjadi ringan dan bersemangat, sehingga pembangunan selesai waktu yang relatif pendek. $11 / 8716$.

${ }^{31}$ Ibn Atsir, Jami' Al-Ushul min Ahadits Ar-Rasul, Kitabul Masjid wama yata 'allqu biha. 
akhlak dan moralitas, persaudaraan dan persatuan, ketinggian ilmu pengetahuan dan nilai-nilai Islam yang berlaku secara universal. ${ }^{32}$

\section{KESIMPULAN}

Perjuangan Pak Natsir juga tokoh-tokoh Islam lainnya, semua lahir dari rahim masjid dan berjuang dalam menyampaikan kebenaran, melalui media masjid. Karena itulah yang ilmu yang pernah diwariskan oleh Rasulullah $\varepsilon$ dalam mempersiapkan kader dalam meneruskan risalah kenabian. Maka adalah benar apa yang dikatakan oleh Sidi Gazalba dalam bukunya "Masjid Pusat Ibadah dan Kebudayaan Islam", "Kehidupan Islam berpangkal di masjid dan berujung di masjid pula." ${ }^{33}$

\section{DAFTAR PUSTAKA}

Abu Muhamad Al-Husain Ibn Mas'ud Ibn Muhammad Al-Farra' AlBaghawy Asy-Syafi'i, Tafsir Al-Baghawy.

Al-Bukhari, Kitab Shalah, Bab: Ashhabul Harab fil Masjid.

Al-Imam Abi al-Faraj 'Abdur Rahman Ibn Al-Jauzi Al-Quraisyi AlBaghdadi, Zadul Masir fi 'Ilmi At-Tafsir, Beirut: Al-maktabu ALIslamy Li Thaba'ati wa An-Nasyri, 1968.

AM. Saefuddin, Fungsi Masjid sebagai Fakultas Dzikir dan Amal. Kumpulan Buletin Dakwah, No. 1 s/d 52 thn. 1987.

Bunga Rampai Ajaran Islam, Jakarta: Dewan Da'wah Islamiyah Indonesia, 1993.

Herman K. Dipojono, Masjid sebagai Pusat Informasi untuk Membentuk Komunitas Belajar Berbasis Masjid, Makalah, e-mail: dipojono@tt.itb.ac.id.

Ibn Hisyam, Sirah Nabawiyah.

M. Natsir, Pendidikan, Pengorbanan, Kepemimpinan Primordialisme dan Nostalgia, Jakarta: Media Da'wah, 1987.

Misbach Malim, Dinamika Da'wah; Dalam Perspektif Al-Qur'an dan AsSunnah, Jakarta: Media Da'wah, 2005.

${ }^{32}$ Nana Rukmana, Masjid dan Da'wah; Merencanakan, Membangun dan Mengelola Masjid, Jakarta: Al-Mawardi Prima, Juli 2002, cet. 1, hal. VI.

${ }^{33}$ Sidi Gazalba, Masjid Pusat Ibadat dan Kebudayaan Islam, Ibid, hal. 124. 
Mohammad Syadid, Konsep Pendidikan Dalam Al-Qur'an, Jakarta: Penebar Salam, 1442 H./2001 M.

Mu'jam Al-Kabir..

Muhammad Natsir, Kearah Pembinaan dan Pembelaan Ummat; Innama Tunsharuna bi Dhu'afa', Djakarta: Jajasan Masdjid Al-Munawwarah. Muhammad Said Ramadhan Al-Buthy, Sirah Nabawiyyah, Jakarta: Rabbani Press, 1999.

Muslim, Shalatul 'Idain, Bab: Ar-Rukhshah fil La'bi Alladzi La Ma’shiyata fih.

Nana Rukmana, Masjid dan Da'wah; Merencanakan, Membangun dan Mengelola Masjid, Jakarta: Al-Mawardi Prima, Juli 2002.

Shahih Al-Bukhari, Bab: Hijrah Nabi $\varepsilon$.

Sidi Gazalba, Masjid Pusat Ibadat dan Kebudayaan Islam, Jakarta: Pustaka Antara, 1975

Sunan Kubra Al-Baihaqy.

Syaikh Salim Al-Hilali, Shahih Kitab Al-Adzkar wa Dha'ifuhu. 